Bojana Aleksić ${ }^{*}$, Vujadin Aleksić2 Ljubica Milović ${ }^{3}$

${ }^{1}$ University of Belgrade, Innovation Centre, Faculty of Technology and Metallurgy, Belgrade, Serbia, ${ }^{2}$ Institute for testing of materialsIMS Institute, Belgrade, Serbia, ${ }^{3}$ University of Belgrade, Faculty of Technology and Metallurgy, Belgrade, Serbia
Scientific paper

ISSN 0351-9465, E-ISSN 2466-2585

UDC:620.165.2:669.445.6

doi: $10.5937 /$ ZasMat1704462A

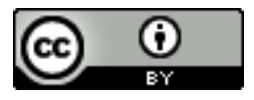

Zastita Materijala 58 (4)

462 - 468 (2017)

\title{
Analysis of the effects of butt welded joints on a carrying capacity of a structure tank
}

\begin{abstract}
In the present paper, after calculation using the Finite Element Method (FEM), stress distribution on the model of a part of the pressure-tank mantle without welded joints (WJ), with transversal $W J$, longitudinal WJ and cross point location of WJ is analyzed. Also, FEM calculation and comparative analysis of the effects of WJ on the stress distribution have been conducted using the tank for liquid carbon dioxide as an example, on which, in addition to the mantle sheet-metal and bottom with necessary openings and elements such as saddles with supports and hangers, transversal and longitudinal butt WJ, have been modelled.
\end{abstract}

Keywords: Finite Element Method, tank, stress distribution on the model, welded joints.

\section{INTRODUCTION}

Structural integrity is a scientific and engineering discipline, which includes analysis of the state and diagnostics of the behavior and failure, assessment of residual strength and exploitation life and revitalization of the structure. The analysis of the state and diagnostics of the behavior of the object structure is carried out on a computer using the FEM. This approach allows the determination of the actual behavior of the object structure, reliable prediction of structural response in exploitation, obtaining of the parameters of selection and decisions, determination of the causes of poor-bad behavior or failure and assessment of exploitation life and the time of reliable operation of the structure [1]. The problems arising in exploitation of the equipment are mostly induced by the geometry the design of which was not good enough and inadequate maintenance. In addition, they are often the result of insufficient resistance of the materials (e.g. corrosion resistance), and in particular that of the welded joints to crack initiation and growth. Also, it is often the case that both of the above factors are present [1].

\footnotetext{
${ }^{*}$ Corresponding author: Bojana Aleksić

E-mail: baleksic@tmf.bg.ac.rs

Paper received: 11. 07. 2017.

Paper corrected: 21. 08. 2017.

Paper accepted: 07. 09. 2017.

Paper is available on the website:

www.idk.org.rs/journal
}

The essential safety requirements for pressure equipment are defined and specified in Supplement-Annex I of the Regulations on the technical requirements for the design, manufacture and conformity assessment of pressure equipment [2]. According to the Regulations [2], calculation of the tank for liquid $\mathrm{CO}_{2}$ using the FEM is equal to other calculation methods. The calculation of FEM have of a global character and does not include local connections, which assumes good connection between the mantle parts and connection with the bottoms, as well as connection between the fittings, supports and hooks with the mantle and bottoms. In other words, it is assumed that all welds have been made properly, in accordance with welding technology, which is valid for the vessel connection at the supporting spots as well. In the engineering analysis of supporting structures, the application of the FEM analysis of structural integrity imposes as inevitable. It is justified due to very low costs with a very high level of the results [1]. This analysis was conducted on the tank for liquid $\mathrm{CO}_{2}$, both on the model of a part of the tank-frame and on the whole tank without and with WJ. The tank discussed in this paper is a horizontal, stable pressure vessel (PV) [3]. Because of its dimensions it can be mobile, too [4] if it is installed on a road vehicle in compliance with regulations pertaining to mobile PV [5]. Based on the technical documentation [3], using SolidWorks program for modeling and COSMOSWorks program for calculation using 
FEM, the model for liquid $\mathrm{CO}_{2}$ tank $[6,7,8]$ and model of a part of mantle-frame without and with WJ loaded by test pressure have been developed and static calculation using the FEM of these models and model of the whole tank without and with WJ made.

\section{THE PRESSURE-TANK FOR LIQUID $\mathrm{CO}_{2}$}

Technical characteristics of the pressure-tank for liquid $\mathrm{CO}_{2}$ are given in Table 1. The appearance and dimensions of the pressure-tank are shown in Figure 1.

Table 1. Characteristics of the pressure-tank for liquid $\mathrm{CO}_{2}$

Tabela 1. Karakteristike rezervoara za tečni $\mathrm{CO}_{2}$

\begin{tabular}{|l|c|}
\hline Highest permissible operating pressure: & $20 \mathrm{bar}$ \\
\hline Calculating pressure, $\mathrm{p}_{\mathrm{c}}:$ & $20 \mathrm{bar}$ \\
\hline Test pressure at $20^{\circ} \mathrm{C}, \mathrm{p}_{\mathrm{t}}=1.3 \cdot \mathrm{p}_{\mathrm{c}}[9]:$ & $26 \mathrm{bar}$ \\
\hline Testing material at $20^{\circ} \mathrm{C}:$ & Water \\
\hline Maximum and minimum wall temperature & $-30 \pm 3^{\circ} \mathrm{C}$ \\
\hline Operating medium: & $21 \mathrm{~m}^{3}$ \\
\hline Volume: & Non-toxique, non-inflammable and non-explosive \\
\hline Empty vessel mass: & $4400 \mathrm{~kg}$ \\
\hline Highest loading mass: & $20440 \mathrm{~kg}$ \\
\hline
\end{tabular}

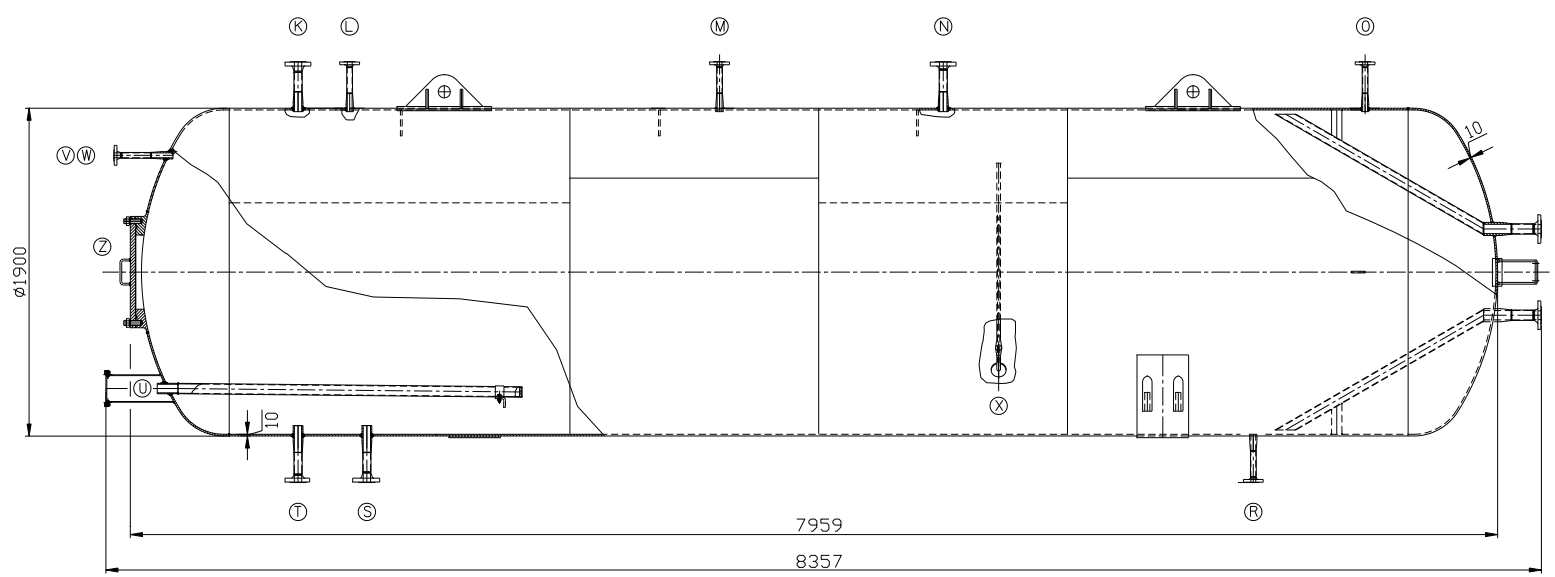

Figure 1. The pressure-tank for liquid $\mathrm{CO}_{2}$, volume $21 \mathrm{~m}^{3}$ [3]

Slika 1. Rezervoar za tečni ugljen dioksid zapremine $21 \mathrm{~m}^{3}$ [3]

Starting from the technical characteristics of the tank and character of $\mathrm{CO}_{2}$, as well as the demands of the regulations in effect at the time of preparation of technical documentation [3], for the base metal of the tank normalized fine-grain steel for pressure vessels was selected. The selection of the grade of material for this purpose was made Table 2. Mechanical properties of the material P 355N L2 [11]

Tabela 2. Mehaničke karakteristike materijala P 355N L2 [11]

\begin{tabular}{|c|c|c|c|c|c|c|}
\hline $\begin{array}{l}\text { Elastic } \\
\text { Modulus } \\
\text { E, GPa }\end{array}$ & $\begin{array}{l}\text { Poisson's } \\
\text { Coefficient v }\end{array}$ & $\begin{array}{c}\text { Yield } \\
\text { Limit } \\
\mathrm{R}_{\mathrm{eH}}, \mathrm{MPa}\end{array}$ & $\begin{array}{l}\text { Tensile } \\
\text { Strength } \\
\mathrm{R}_{\mathrm{m}}, \mathrm{MPa} \\
\end{array}$ & $\begin{array}{c}\text { Elongation } \\
A_{\min }\left(L=5 d_{0}\right), \%\end{array}$ & \multicolumn{2}{|c|}{$\begin{array}{c}\text { Toughness } \\
\text { ISO - KV, } \\
A_{\mathrm{V}}, \mathrm{J}\end{array}$} \\
\hline \multirow{2}{*}{200} & \multirow{2}{*}{0.3} & \multirow{2}{*}{355} & \multirow{2}{*}{$490-630$} & \multirow{2}{*}{$>22$} & $+20^{\circ} \mathrm{C}$ & 63 \\
\hline & & & & & $-50^{\circ} \mathrm{C}$ & 27 \\
\hline
\end{tabular}

From sheet material, P 355N L2, frame, bottom and saddle of the tank for liquid $\mathrm{CO}_{2}$ were made. From forging material, P 355N L2, the flanges and according to the then applicable standard with mandatory application of JUS M.E2.516 [10]. The grade of the selected steel, according to European standards EN 10028-3 [11], defined as P 355N L2 fine grain steel. Mechanical properties of the tank material are shown in Tab. 2. 
conducted using the process of arc welding as regulated by the technology of welding.

\section{INFLUENCE OF MATERIAL HETEROGENEITY ON THE CARRYING CAPACITY OF A STRUCTURE}

With its heterogeneous structure and different mechanical properties of its constituents, welded joints represent a complex problem when it is necessary to assess the integrity of a welded structure, such as the pressure vessel (PV). The behaviour of a precracked welded joint is affected by several factors:

- material heterogeneity (BM, WM, HAZ),

- residual stresses (due to welding and geometrical imperfections),

- disrupted strain and

- imperfection of geometry (ratio of the dimensions of a welded joint).

The process of welding induces differences in the microstructures of some parts of a joint, which leads to differences in the mechanical properties of the base metal, heat-affected zone and weld metal, i.e. heterogeneity. The effect of heterogeneity (mismatch) is defined by the ratio of yield stress of weld metal (WM) and base metal (BM):

$\mathbf{M}=\sigma_{W M} / \sigma_{B M}$, where:

$\sigma_{\mathrm{WM}}-$ yield stress of weld metal, and

$\sigma_{\mathrm{BM}}-$ yield stress of base metal.

If the heterogeneity coefficient is as follows:

$\mathbf{M}<1$, WM has lower value of yield stress than BM - undermatch joint;

$\mathbf{M}>\mathbf{1}$, WM has higher value of yield stress than $\mathrm{BM}$ - overmatch joint;

$M=1, W M$ and $B M$ have equal value of yield stress - evenmatch joint.

This method takes into account only the effect of different values of yield stress on the behavior of materials. However, other properties such as modulus of elasticity, coefficient of heat conductivity or coefficient of strain hardening may also have different values in the weld metal and base metal. Same as it is impossible to avoid the defects in a welded joint, it is impossible not to reckon with the heterogeneity of the material of a welded joint. Therefore, it is essential to pay proper attention to the effect of heterogeneity on the integrity of welded structures. Practically, the effect of the material heterogeneity is usually reduced to the effect of mismatch, i.e. the effect of difference of the resistance to failure between WM and BM, which is analyzed in this paper on the model of a part of the tank frame and then on the model of the whole tank without and with $\mathrm{WJ}$, too.

\section{CALCULATION USING THE FEM}

FEM is one of the modern methods of numerical analysis. Its application was first started in the field of calculation of engineering structures. By analogy with the procedure for calculation of the frames, which was known in the statics of structures, the problem of plane stress state (PSS) was solved [12]. From this first application, for which one can say to appear intuitively, without necessary theoretical foundations, in a short period of time the FEM developed into a special scientific field, with wide application in solving crucial problems of mathematics, physics, and in particular continuum mechanics. The rapid development of the FEM went along with the development of modern electronic computers and their application in various fields of science and engineering practices [13]. Constantly present problem of modelling is to select the type of finite element and finenessrefinement of discretization of the physical model. When the model is not known well enough, first that should be done is to make calculation with a rough model (the minimum number of nodes and elements). Static and dynamic identification with a rough model provides assessment of the validity of the model from the point of view of boundary conditions, selection of the type or types of finite elements, discretization and modelling of the load. Preferably, the single structure should have more rough models. Most frequently, it is used for determination of the overall response of the structure [14]. In developing the model for the calculation of the FEM in the SolidWorks program, the basic dimensions of the tank for liquid $\mathrm{CO}_{2}$ given in the technical documentation and shown in Figure 1 were used. In modelling of the tank for liquid $\mathrm{CO}_{2}$, in addition to the main planes and the planes arising after modelling of a certain part, it was necessary to construct auxiliary planes as well. Also, in order to precisely define the elements such as carriers, side holes and hooks-eyes, it was necessary to draw auxiliary (design) drawings as well [6].

\section{CALCULATION OF A PART OF THE TANK FRAME WITHOUT AND WITH WJ USING THE FEM}

Based on calculation of the thickness of cylindrical jacket and bottom-wall of the tanks for liquid $\mathrm{CO}_{2}$ with volume $\mathrm{V}=23 \mathrm{~m}^{3}$, an outer diameter, $D_{0}=1900 \mathrm{~mm}$ and test pressure, $p_{t}=26$ bar (JUS M.E2.250 [9]), made of the material P 355N L2 [11], according to standard SRPS EN 13445-3 [4, 15], the thickness is $t=10 \mathrm{~mm}$. This calculation is 
based on the formulas for calculation of stresses in the thin walls of the shells and on the empirical safety factors [16]. Based on these formulas it has been calculated that the tangential stress $\sigma_{t}=$ 245.7 MPa, and the axial stress $\sigma_{\mathrm{a}}=122.8 \mathrm{MPa}$. In the first calculation case the cylindrical tank mantle was manufactured by butt welding with WM yield strength $\sigma_{\mathrm{WM}}=350 \mathrm{MPa}$ and the heterogeneity coefficient $M=1$. In the second one the value of WM yield strength was $\sigma_{W M}=300 \mathrm{MPa}$ and the heterogeneity coefficient $\mathrm{M}=0.85$. Calculation results show that the stress distribution of the whole structure depends only of the weld joint model (shape), but it is independent of the heterogeneity coefficient, Figure 2.

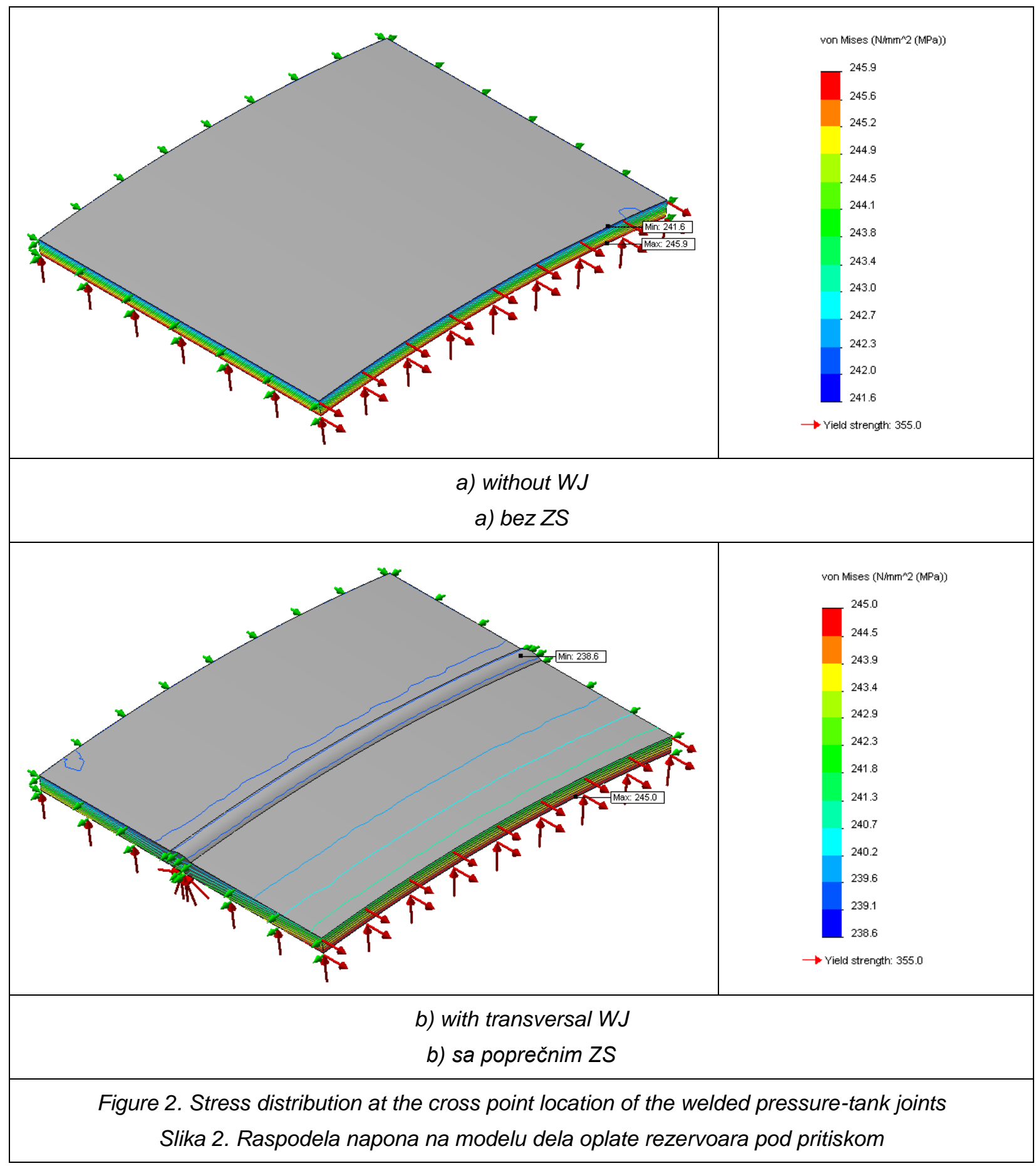




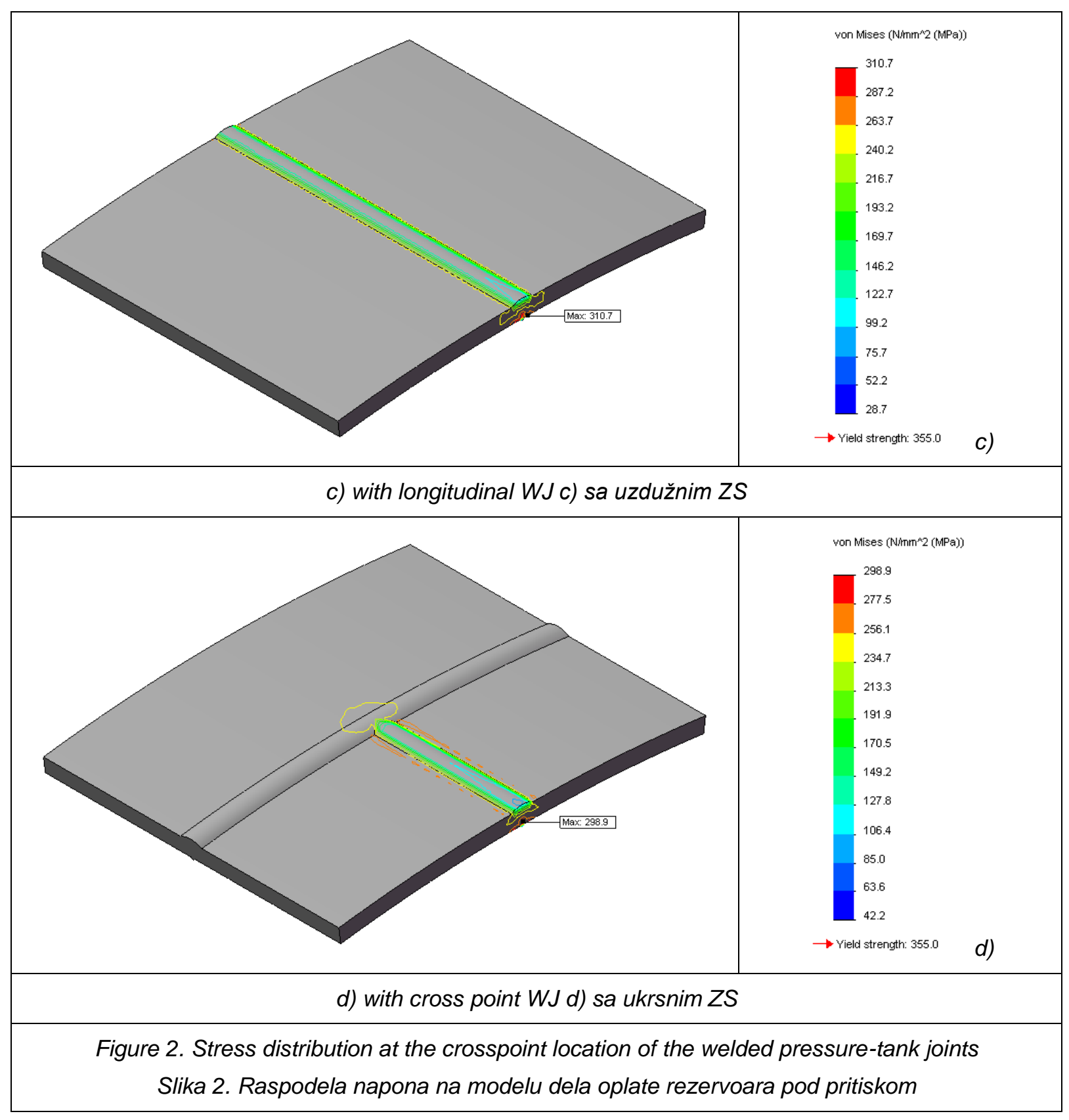

Stress values in the WJ, obtained by FEM calculation on the part of the tank mantle exposed to the test pressure, are presented in Tab. 3.

Table 3. Comparative stress values on the part of the pressure-tank mantle

Tabela 3. Uporedne vrednosti napona na delu oplate rezervoara pod pritiskom

\begin{tabular}{|c|c|c|c|c|c|}
\hline \multirow{2}{*}{$\begin{array}{c}\text { The part of the tank mantle exposed to } \\
\text { pressure of } 2.6 \mathrm{MPa}\end{array}$} & \multicolumn{2}{|c|}{ FEM (von Mises stresses) } & $\begin{array}{c}\text { Formulas } \\
\text { (Normal stresses) }\end{array}$ \\
\cline { 2 - 5 } & & $\sigma_{\min }, \mathrm{MPa}$ & $\sigma_{\max }, \mathrm{MPa}$ & Figure & $\sigma, \mathrm{MPa}$ \\
\hline \multirow{2}{*}{ Without WJ, } & Transversal & 241.6 & 245.9 & Figure 2a & 245.7 \\
\cline { 2 - 6 } & Longitudinal & & 245.0 & Figure 2b & 122.8 \\
\hline \multirow{3}{*}{ With Butt } & transversal WJ & 238.6 & 310.7 & Figure 2c & $/$ \\
\cline { 2 - 5 } & longitudinal WJ & 28.7 & 298.9 & Figure 2d & $/$ \\
\cline { 2 - 5 } & crosspoint WJ & 42.2 & & \\
\hline
\end{tabular}




\section{STRESS DISTRIBUTION ON THE MODEL OF THE PRESSURE-TANK MANTLE WITHOUT AND WITH WJ}

Mechanical model for FME calculation of the liquid $\mathrm{CO}_{2}$ pressure tank was made with 104397 nodes and 52563 plate elements. In order to get more accurate results, the fine mashing around $\mathrm{WJ}$ with the ratio of 1.2 was performed. In case when the tank is positioned on supports, the calculation was done with internal pressure of $2.6 \mathrm{MPa}$.

To see the difference of stress distribution, two models of the tanks were made (with and without WJ), and after the FEM calculation the comparative analysis of the stress distribution was also conducted, Figure 3.

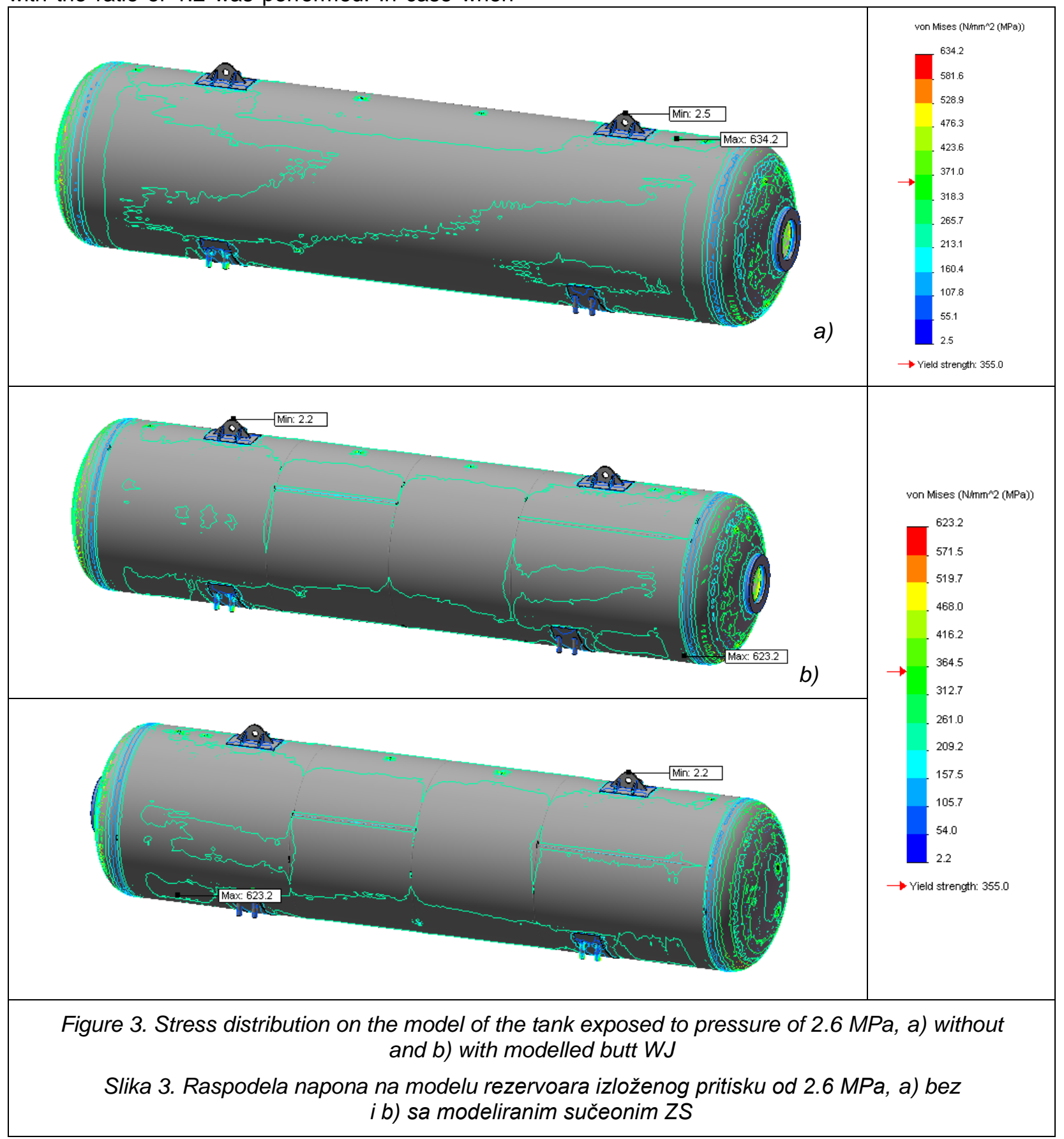

\section{CONCLUSIONS}

Based on the results and analysis of the stress and strain state, it can be concluded that stress and strain are within the permissible, except for the stress around the terminal $\mathrm{L}$, model without $\mathrm{WJ}$, and the terminal $\mathrm{T}$, model with $\mathrm{WJ}$, which represents the stress concentration around the holes of these terminals modelled as a hole in the 
tank frame, which is not an actual picture of the terminal, so that such a result was expected. More precise stress distribution around the terminals requires a more realistic model on these locations.

By analyzing the stress distribution after FEM calculation one can see a completely different picture of the stress distribution on the tank modelled with and without a model of butt WJ, as expected, which tells us that to fully understand the behaviour of welded structures the FEM calculation on the model on which the WJ are also modelled is required.

\section{Acknowledgment}

This work is a contribution to the Ministry of Education and Science of the Republic of Serbia funded Project TR 35011.

\section{REFERENCES}

[1] T.Maneski (2002) Rešeni problemi čvrstoće konstrukcija, monografija, knjiga, Mašinski fakultet, Beograd.

[2] Pravilnik o tehničkim zahtevima za projektovanje, izradu i ocenjivanje usaglašenosti opreme pod pritiskom (Službeni glasnik RS broj 87/2011)

[3] Projekat "Proračun čvrstoće noseće strukture rezervoara za TUD OD $21 \mathrm{~m} 3$ " (2001) Institut GOŠA, Beograd.

[4] V.Aleksić, D.Jaković, Z.Kovačević (2011) Solid Works used for the process of optimization of supporting structure of a pressure vessel. International virtual journal for science, technics and innovations for the industry „MTM MACHINES TECHNOLOGIES MATERIALS“", 5(6), 3-6.

[5] Pravilnik o tehničkim normativima za pokretne $i$ zatvorene sudove za komprimirane, tečne i pod pritiskom rastvorene gasove ("SI. list SFRJ", br. 25/80 i 9/86, "SI. list SRJ", br. 21/94, 56/95 i 1/2003, "SI. glasnik RS", br. 21/2010 i 8/2012).
[6] B.Aleksić (2015) Primena numeričkog postupka u optimizaciji noseće konstrukcije posude pod pritiskom, Završni master rad, Univerzitet $u$ Beogradu, Tehnološko-metalurški fakultet, Beograd.

[7] B.Aleksić, V.Aleksić, Lj.Milović (2016) Finite element method pressure vessel calculation and analysis of the effects of the butt welded joints on a carrying capacity of a structure, Book of Abstracts, 16th International Conference on New Trends in Fatigue and Fracture (NT2F16), may 24-27, Dubrovnik, Croatia, str. 153 - 154.

[8] B.Aleksić, V.Aleksić, Lj.Milović (2017) Analiza opravdanosti modeliranja sučeono zavarenih spojeva kod proračuna posuda pod pritiskom, V Međunarodni kongres „Inženjerstvo, ekologija i materijali u procesnoj industriji", Jahorina, Bosna i Hercegovina, 15.03.-17.03., CD, str. 1136-1144.

[9] JUS M.E2.250:1989. Posude pod pritiskom. Proračun delova pod pritiskom. Opšti zahtevi. Savezni zavod za standardizaciju. Beograd.

[10] JUS M.E2.516:1989. Stabilni sudovi pod pritiskom za tečni ugljendioksid. Tehnički uslovi. Savezni zavod za standardizaciju. Beograd.

[11] EN 10028-3:1992. Flat products made of steels for pressure proposes - Part 3: Weldable fine grain steels, normalized. European Committee for Standardization. Brussels.

[12] A.Hrenikoft (1941) Solution of Problems in Elasticity by the Framework Method, J.Appl. Mech, 8(1), 254261.

[13] M.Sekulović (1988) Metod konačnih elemenata, Građevinska knjiga, Beograd.

[14] T.Maneski (1998) Kompjutersko modeliranje i proračun struktura, monografija, Mašinski fakultet, Beograd.

[15] SRPS EN 13445-3:2010. Posude pod pritiskom koje nisu izložene plamenu - Deo 3: Projektovanje. Institut za standardizaciju. Beograd.

[16] D.R.Moss (2004) Pressure vessel design manual, third edition, Elsevier.

\title{
IZVOD
}

\section{ANALIZA UTICAJA SUČEONO ZAVARENIH SPOJEVA NA NOSIVOST KONSTRUKCIJE REZERVOARA}

$U$ radu je posle proračuna metodom konačnih elemenata (MKE) analizirana raspodela napona na modelu dela oplate rezervoara pod pritiskom bez zavarenih spojeva (ZS), sa obimnim ZS, podužnim ZS i ukrsnim mestom ZS. Takođe, u radu je na primeru rezervoara za tečni ugljendioksid, na kome su pored limova oplate i danaca sa potrebnim otvorima i elementima kao što su sedla sa osloncima $i$ uške modelirani obimni i podužni sučeoni ZS, urađen proračun MKE $i$ uporedna analiza uticaja ZS na raspodelu napona.

Ključne reči: Metoda Konačnih Elemenata, rezervoar, raspodela napona na modelu, zavareni spojevi.

\author{
Naučni rad \\ Rad primljen: 11. 07. 2017. \\ Rad korigovan: 21. 08. 2017. \\ Rad prihvaćen: 07. 09. 2017. \\ Rad je dostupan na sajtu: www.idk.org.rs/casopis
}

(C) 2017 Authors. Published by Inženjersko društvo za koroziju. This article is an open access article distributed under the terms and conditions of the Creative Commons Attribution 4.0 International license (https://creativecommons.org/licenses/by/4.0/) 